\title{
Hymenobacter daecheongensis sp. nov., isolated from stream sediment
}

\author{
Correspondence \\ Wan-Taek Im \\ wandra@kaist.ac.kr \\ Feng-Xie Jin \\ fxjin@dlpu.edu.cn
}

\author{
Jin-Li Xu, ${ }^{1,2}$ Qing-Mei Liu, ${ }^{1}$ Hong-Shan Yu, ${ }^{2}$ Feng-Xie Jin, ${ }^{2}$ \\ Sung-Taik Lee ${ }^{1}$ and Wan-Taek $\mathrm{Im}^{1}$ \\ ${ }^{1}$ Department of Biological Sciences, Korea Advanced Institute of Science and Technology, 373-1 \\ Guseong-dong, Yuseong-gu, Daejeon 305-701, Republic of Korea \\ ${ }^{2}$ College of Bio \& Food Technology, Dalian Polytechnic University, Qinggong-yuan No. 1, \\ Ganjingzi-qu, Dalian 116034, PR China
}

\begin{abstract}
A Gram-negative, strictly aerobic, non-spore-forming, rod-shaped, red-pink bacterium, designated strain Dae $14^{\top}$, was isolated from stream sediment collected near Daecheong Dam, South Korea, and its taxonomic position was investigated by using a polyphasic approach. Phylogenetic analysis of $16 \mathrm{~S}$ rRNA gene sequences showed that strain Dae $14^{\top}$ belonged to the genus Hymenobacter. Sequence similarities between strain Dae $14^{\top}$ and the type strains of Hymenobacter species with validly published names ranged from 91.3 to $94.3 \%$. The predominant cellular fatty acids of strain Dae $14^{\top}$ were iso- $\mathrm{C}_{15: 0}, \mathrm{C}_{16: 1} \omega 5 \mathrm{c}$, summed feature 5 (iso- $\mathrm{C}_{17: 1} \mathrm{I}$ and/or anteiso- $\mathrm{C}_{17: 1} \mathrm{~B}$ ) and iso- $\mathrm{C}_{16: 0}$. The DNA G+C content was $62.2 \mathrm{~mol} \%$. Results of phylogenetic, chemotaxonomic and phenotypic characterization indicated that strain Dae $14^{\top}$ can be distinguished from all known Hymenobacter species and represents a novel species, for which the name Hymenobacter daecheongensis sp. nov. is proposed, with Dae $14^{\top}$ $\left(=\right.$ KCTC $22258^{\top}=$ LMG $\left.24498^{\top}\right)$ as the type strain.
\end{abstract}

The genus Hymenobacter was first described by Hirsch et al. (1998) and was known to be unique because of its relatively high DNA G + C content (55-65 mol\%); other members of the family 'Flexibacteraceae' in the class 'Sphingobacteria' (Garrity \& Holt, 2001) have low G+C contents (27$48 \mathrm{~mol} \%$ ) (Buczolits et al., 2002). At the time of writing, the genus Hymenobacter comprised the following 10 species: Hymenobacter roseosalivarius (Hirsch et al., 1998); $H$. actinosclerus (Collins et al., 2000); H. aerophilus (Buczolits et al., 2002); H. norwichensis, H. ocellatus, $H$. gelipurpurascens and $H$. chitinivorans (Buczolits et al., 2006); H. rigui (Baik et al., 2006); H. xinjiangensis (Zhang et al., 2007); and H. soli (Kim et al., 2008).

During the course of a study on the culturable aerobic bacteria of soils and streams near Daejeon, South Korea, a large number of novel bacterial strains was isolated (Im et al., 2003). One of these isolates, strain Dae $14^{\mathrm{T}}$, was found to be a member of the genus Hymenobacter and was subjected to further taxonomic investigation. In this study, its genotypic, chemotaxonomic and phenotypic characteristics were analysed in order to establish its phylogenetic affiliation.

The GenBank/EMBL/DDBJ accession number for the 16S rRNA gene sequence of strain Dae $14^{\top}$ is EU370958.

A table showing cellular fatty acid data for strain Dae $14^{\top}$ and related strains is available as supplementary material with the online version of this paper.
Strain Dae $14^{\mathrm{T}}$ was isolated from stream sediment collected near Daecheong Dam, South Korea, in May 2003. The sediment sample was thoroughly suspended in $50 \mathrm{mM}$ phosphate buffer ( $\mathrm{pH} 7.0$ ) and the suspension was spread onto R2A agar (Scharlau). After incubation at $25{ }^{\circ} \mathrm{C}$ for 2 weeks, colonies that formed were picked and subcultured several times to confirm that they were pure cultures. Isolates were cultured routinely on $\mathrm{R} 2 \mathrm{~A}$ agar at $30{ }^{\circ} \mathrm{C}$ and maintained as glycerol suspensions $\left(20 \%\right.$, w/v) at $-70{ }^{\circ} \mathrm{C}$.

PCR-mediated amplification of the 16S rRNA gene and sequencing of purified PCR products were carried out according to Ten et al. (2008). The near-complete $16 \mathrm{~S}$ rRNA gene sequences were compiled using SEQMAN software (DNASTAR). Related sequences were obtained from Ribosomal Database Project II (Cole et al., 2005) and GenBank (Benson et al., 2005) and multiple alignment was done using the program CLUSTAL_X (Thompson et al., 1997). Some ambiguous sequences, gaps, and the $5^{\prime}$ and $3^{\prime}$ ends of the alignment were edited manually using the program BIOEDIT (Hall, 1999). Phylogenetic trees were reconstructed by using the neighbour-joining method (Saitou \& Nei, 1987) in the program MEGA3 (Kumar et al., 2004) with bootstrap analysis based on 1000 resamplings (Felsenstein, 1985). Distance matrices were calculated by using the Kimura twoparameter model (Kimura, 1983).

The Gram reaction was performed by using the nonstaining method as described by Buck (1982). Cell 
morphology was examined by light microscopy (E600; Nikon). Catalase activity was determined by bubble production in $3 \%(\mathrm{v} / \mathrm{v}) \mathrm{H}_{2} \mathrm{O}_{2}$ and oxidase activity was determined using $1 \%(\mathrm{w} / \mathrm{v})$ tetramethyl $p$-phenylenediamine. The presence of flexirubin-type pigments was determined by suspending cells in $20 \% \mathrm{KOH}$ (Fautz \& Reichenbach, 1980). Enzyme activities, substrates that could be utilized as sole carbon sources and some physiological characteristics were determined with API ZYM, API 20E and API 20NE galleries according to the instructions of the manufacturer (bioMérieux). Because of the failure of carbon assimilation tests using API test strips, agar plates for single-carbon-source assimilation studies were made manually using a defined agar medium containing basal salt media composed of $\left(1^{-1}\right): 1.8 \mathrm{~g}$ $\mathrm{K}_{2} \mathrm{HPO}_{4}, 1.08 \mathrm{~g} \mathrm{KH}_{2} \mathrm{PO}_{4}, 0.5 \mathrm{~g} \mathrm{NaNO}_{3}, 0.5 \mathrm{~g} \mathrm{NH}_{4} \mathrm{Cl}, 0.1 \mathrm{~g}$ $\mathrm{KCl}, 0.1 \mathrm{~g} \mathrm{MgSO}_{4}, 0.05 \mathrm{~g} \mathrm{CaCl}_{2}$ and $15 \mathrm{~g}$ agar. After autoclaving, a vitamin solution (Widdel \& Bak, 1992), trace element solution SL-10 (Widdel et al., 1983) and selenite/tungstate solution (Tschech \& Pfennig, 1984) were added to this medium and filter-sterilized carbon sources were also added (individually at $0.1 \%$, w/v). Growth was examined visually on plates incubated at $30{ }^{\circ} \mathrm{C}$ for up to 7 days. A negative control well containing no carbon source was included. A positive control culture was grown in a well containing R2A agar.

Anaerobic growth was assessed in a serum bottle containing R2A broth supplemented with sodium thioglycollate $\left(1 \mathrm{~g} \mathrm{l}^{-1}\right)$ and nitrogen gas as the gas phase. Tests for degradation of DNA [in which DNase agar (Scharlau) plates were flooded with $1 \mathrm{M} \mathrm{HCl}$, casein, chitin, starch (Atlas, 1993), lipid (Kouker \& Jaeger, 1987), xylan and cellulose (Ten et al., 2004) were performed and evaluated after 10 days. Growth at different temperatures $(4,15,20$, $25,30,37$ and $\left.42{ }^{\circ} \mathrm{C}\right)$ and $\mathrm{pH}(\mathrm{pH} 5.0-10.0$ at intervals of $0.5 \mathrm{pH}$ units) was assessed after 7 days incubation. Salt tolerance was tested after incubation for 7 days on R2A medium supplemented with 1-10\% (w/v) NaCl. Growth on nutrient agar, trypticase soy agar and MacConkey agar was also evaluated at $30{ }^{\circ} \mathrm{C}$.

For the measurement of chromosomal DNA G+C content, the genomic DNA of the isolate was extracted and purified as described by Moore \& Dowhan (1995) and determined as described by Mesbah \& Whitman (1989) using reversed-phase HPLC. Isoprenoid quinones were extracted with chloroform/methanol $(2: 1, \mathrm{v} / \mathrm{v})$, evaporated under a vacuum and then re-extracted in n-hexane/water $(1: 1, v / v)$. The crude $n$-hexane/quinone solution was purified using Sep-Pak Vac Silica Cartridges (Waters) and subsequently analysed by HPLC, as described by Hiraishi et al. (1996). Cellular fatty acid profiles were determined for cells grown on R2A agar for 3 days at $30{ }^{\circ} \mathrm{C}$. Cellular fatty acids were saponified, methylated and extracted according to the protocol of the Sherlock Microbial Identification System (MIDI). The fatty acids analysed by GC (Hewlett Packard 6890) were identified by using the Microbial Identification software package (Sasser, 1990).
An almost-complete 16S rRNA gene sequence (1468 bp in length) was obtained for strain Dae $14^{\mathrm{T}}$. Comparisons with corresponding sequences showed that strain Dae $14^{\mathrm{T}}$ had highest levels of similarity to $H$. chitinivorans $\operatorname{Txc1}^{\mathrm{T}}(94.3 \%)$, $H$. actinosclerus CCUG $39621^{\mathrm{T}}(93.4 \%), H$. roseosalivarius DSM $11622^{\mathrm{T}}(93.0 \%)$, H. gelipurpurascens $\operatorname{Txg}^{\mathrm{T}}(93.0 \%)$, $H$. aerophilus $\mathrm{I} / 26-\mathrm{Cor}^{\mathrm{T}}(92.3 \%), H$. rigui $\mathrm{WPCB}^{\mathrm{T}} 1^{\mathrm{T}}$ $(92.5 \%), H$. xinjiangensis $\mathrm{X} 2-\lg ^{\mathrm{T}}(92.0 \%), H$. ocellatus $\mathrm{Myx}$ $2105^{\mathrm{T}}(91.6 \%)$, H. soli $\mathrm{PB}^{\mathrm{T}}{ }^{\mathrm{T}}(91.3 \%)$ and H. norwichensis DSM $15439^{\mathrm{T}}(91.3 \%)$. In the neighbour-joining tree constructed using 16S rRNA gene sequences of the novel strain and strains of the genus Hymenobacter, strain Dae $14^{\mathrm{T}}$ clustered within the radiation of the genus Hymenobacter, but was separate from recognized Hymenobacter species. Its distinct phylogenetic position was supported by high bootstrap values (96-100 \%) (Fig. 1). Low levels of similarity with respect to recognized Hymenobacter species (91.3-94.3\%) indicate that strain Dae $14^{\mathrm{T}}$ represents a novel species.

Cells of strain Dae $14^{\mathrm{T}}$ were Gram-negative, non-motile, non-spore-forming and rod-shaped. Colonies grown on R2A agar for 3 days were circular, entire, smooth, redpink, transparent and $0.5-2.0 \mathrm{~mm}$ in diameter. Cells became larger (approx. $10 \mu \mathrm{m}$ in length) after 7 days incubation. Physiological characteristics of strain Dae $14^{\mathrm{T}}$ are summarized in the species description. Selected characteristics that differentiate strain Dae $14^{\mathrm{T}}$ from related species of the genus Hymenobacter are shown in Table 1.

MK-7 was the predominant isoprenoid quinone. The DNA $\mathrm{G}+\mathrm{C}$ content of strain Dae $14^{\mathrm{T}}$ was $62.2 \mathrm{~mol} \%$; such relatively high values are unique to the genus Hymenobacter, distinguishing it from other genera of the family 'Flexibacteraceae'. The major cellular fatty acids of strain Dae $14^{\mathrm{T}}$ were iso- $\mathrm{C}_{15: 0}$, $\mathrm{C}_{16: 1} \omega 5 c$, summed feature 5 (iso- $\mathrm{C}_{17: 1} \mathrm{I}$ and/or anteiso- $\mathrm{C}_{17: 1}$ B) and iso- $\mathrm{C}_{16: 0}$. Strain Dae $14^{\mathrm{T}}$ had a similar profile to other members of the genus qualitatively, but it showed quantitative differences such as high proportions of iso- $\mathrm{C}_{16: 0}$ and iso- $\mathrm{C}_{16: 1}$ $\mathrm{H}$ and a low proportion of summed feature 4 (iso- $\mathrm{C}_{15: 0} 2-\mathrm{OH}$ and/or $\mathrm{C}_{16: 1} \omega 7 c / t$ ) (see Supplementary Table S1, available in IJSEM Online).

Phenotypic and phylogenetic analysis, plus the relatively high $\mathrm{G}+\mathrm{C}$ content, indicated that strain Dae $14^{\mathrm{T}}$ belongs to the genus Hymenobacter. However, low levels of $16 \mathrm{~S}$ rRNA gene sequence similarity $(91.3-94.3 \%)$ between strain $\mathrm{Dae} 14^{\mathrm{T}}$ and members of the genus, its quantitative fatty acid profiles and its differential phenotypic characteristics support the proposal that strain Dae $14^{\mathrm{T}}$ represents a novel species. Therefore, on the basis of the data and observations described above, strain Dae $14^{\mathrm{T}}$ represents a novel species of the genus Hymenobacter, for which the name Hymenobacter daecheongensis sp. nov. is proposed.

\section{Description of Hymenobacter daecheongensis sp. nov.}

Hymenobacter daecheongensis (dae.che.ong.en'sis. N.L. masc. adj. daecheongensis referring to the Daecheong Dam, from where the type strain was isolated). 


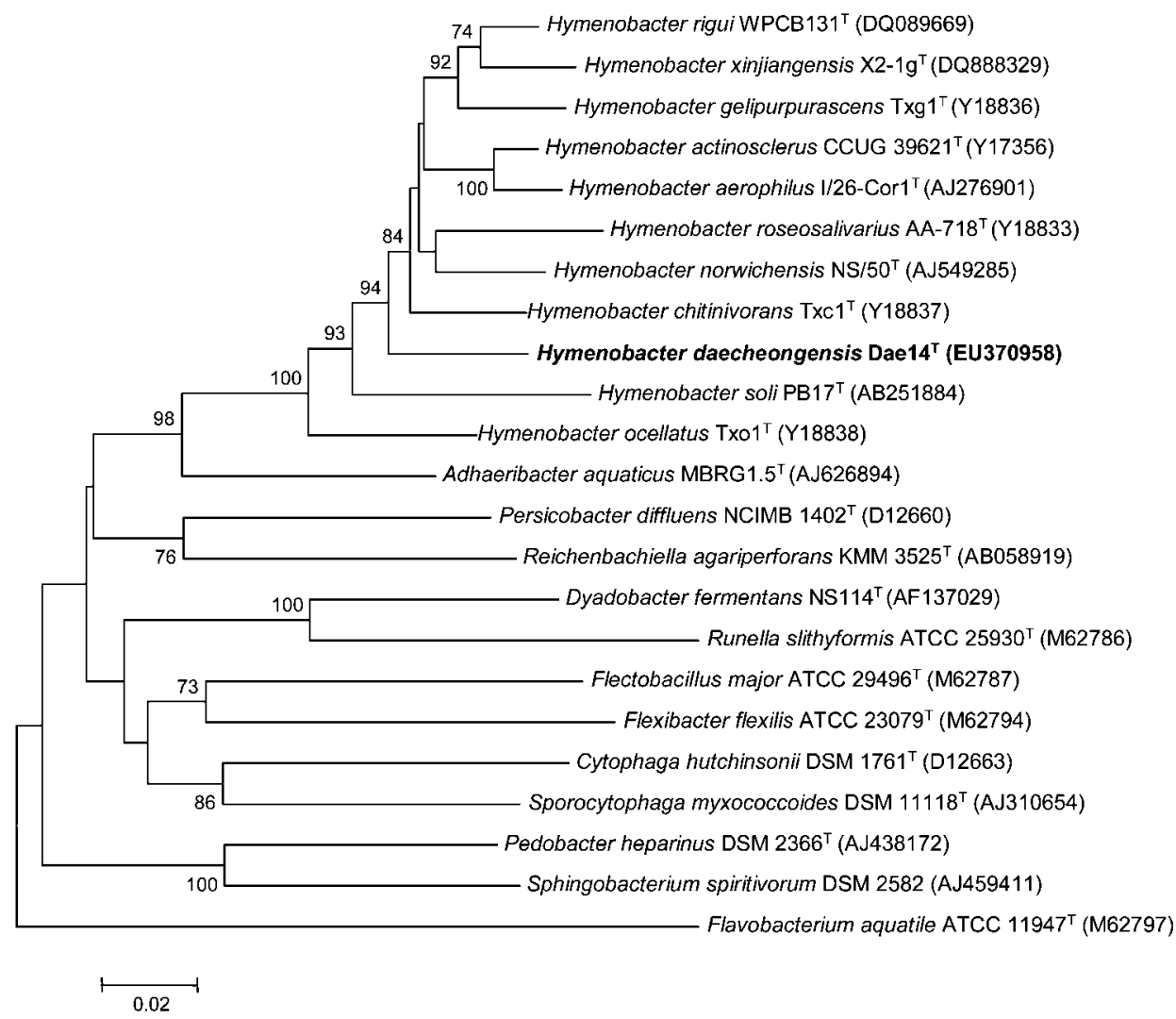

Fig. 1. Neighbour-joining phylogenetic tree based on $16 \mathrm{~S}$ rRNA gene sequences of strain Dae $14^{\top}$ and related strains. Bootstrap values (percentages based on 1000 replications) $>70 \%$ are shown at branch points. Bar, 2 substitutions per 100 nucleotide positions.

Cells are Gram-negative, rod-shaped, non-spore-forming and non-motile. Obligately aerobic and chemo-organotrophic. Cells are $0.6-1.0 \mu \mathrm{m}$ wide and $2.0-5.0 \mu \mathrm{m}$ long. Cells become larger, around $10 \mu \mathrm{m}$ in length, after 7 days incubation. Cells grow on R2A agar, but not on trypticase soy agar or MacConkey agar. Colonies on R2A agar are circular, entire, smooth and red-pink. No flexirubin-type pigments are formed. Oxidase- and catalase-positive. Grows at $4-30{ }^{\circ} \mathrm{C}$ and $\mathrm{pH} 5.0-10.0$, but not at $37^{\circ} \mathrm{C}$. The presence of more than $1 \% \mathrm{NaCl}$ inhibits growth on $\mathrm{R} 2 \mathrm{~A}$ agar. No growth occurs under anaerobic and denitrifying conditions. The major respiratory quinone is MK-7. The major cellular fatty acids are iso- $\mathrm{C}_{15: 0}, \mathrm{C}_{16: 1} \omega 5 c$, summed feature 5 (iso- $\mathrm{C}_{17: 1} \mathrm{I}$ and/or anteiso- $\mathrm{C}_{17: 1} \mathrm{~B}$ ) and iso$\mathrm{C}_{16: 0}$. Hydrolyses skim milk, but not xylan, starch, cellulose, chitin or olive oil. Positive for assimilation of the following substrates: D-galactose, L-sorbose, D-arabinose, L-xylose, $\mathrm{N}$-acetyl-D-glucosamine, formate, acetate, propionate, 3-hydroxybutyrate, valerate, caprate, maleic acid, phenylacetate, benzoic acid, 3-hydroxybenzoate, salicin, citrate, lactate, malate, malonate, succinic acid, glutaric acid, tartaric acid, itaconate, adipate, suberate, oxalic acid, lactose, raffinose, D-adonitol, D-mannitol, Dsorbitol, xylitol, amygdalin, glycerol, glycogen, inulin, histidine, proline and tyrosine. Negative for assimilation of the following substrates: D-glucose, D-mannose, Lrhamnose, D-fructose, L-arabinose, D-ribose, D-xylose, pyruvic acid, fumaric acid, 4-hydroxybenzoate, cellobiose, maltose, melibiose, sucrose, trehalose, gluconate, dulcitol, inositol and dextran. Negative for arginine dihydrolase, lysine decarboxylase, ornithine decarboxylase, urease and tryptophan deaminase activities and production of hydrogen sulfide, acetoin and indole. Gelatinase activity is positive (API 20E). API 20NE tests for nitrate reduction, arginine dihydrolase, urease and aesculin hydrolysis are negative. According to the API ZYM gallery (bioMérieux), positive for acid phosphatase, alkaline phosphatase, esterase lipase (C8), esterase (C4) and leucine arylamidase and negative for cystine arylamidase, $\alpha$-chymotrypsin, $\alpha$-fucosidase, $\beta$-glucuronidase, lipase (C14), $\alpha$-mannosidase, trypsin, $\beta$-galactosidase, $\alpha$-glucosidase, naphthol-AS-BIphosphohydrolase, valine arylamidase, $N$-acetyl- $\beta$-glucosaminidase, $\alpha$-galactosidase and $\beta$-glucosidase.

The type strain, Dae $14^{\mathrm{T}}\left(=\right.$ KCTC $22258^{\mathrm{T}}=\mathrm{LMG} 24498^{\mathrm{T}}$ ), was isolated from sediment of a stream near Daecheong Dam, South Korea. The DNA G +C content of the type strain is $62.2 \mathrm{~mol} \%$. 
Table 1. Differential characteristics of strain Dae $14^{\top}$ and members of the genus Hymenobacter

Strains: 1, Dae14 ${ }^{\mathrm{T}}$ (Hymenobacter daecheongensis sp. nov.); 2, H. soli $\mathrm{PB}^{\mathrm{T}}{ }^{\mathrm{T}} ; 3$, H. ocellatus $\mathrm{Myx} 2105^{\mathrm{T}} ; 4$, H. roseosalivarius DSM $11622^{\mathrm{T}} ; 5$, H.

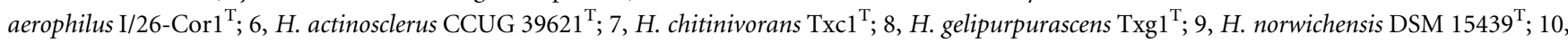
H. rigui WPCB131 ${ }^{\mathrm{T}} ; 11$, H. xinjiangensis X2-1g ${ }^{\mathrm{T}}$. Data for reference strains are from Hirsch et al. (1998), Collins et al. (2000), Buczolits et al. (2002, 2006), Baik et al. (2006), Zhang et al. (2007) and Kim et al. (2008). +, Positive; -, negative; (+), weakly positive; ND, not determined. All strains are negative for assimilation of $\mathrm{L}$-arabinose and indole production.

\begin{tabular}{|c|c|c|c|c|c|c|c|c|c|c|c|}
\hline Characteristic & 1 & 2 & 3 & 4 & 5 & 6 & 7 & 8 & 9 & 10 & 11 \\
\hline \multicolumn{12}{|l|}{ Growth in/at: } \\
\hline $1 \% \mathrm{NaCl}$ & - & - & + & + & + & ND & $(+)$ & $(+)$ & - & + & - \\
\hline $3 \% \mathrm{NaCl}$ & - & - & + & ND & $(+)$ & ND & $(+)$ & $(+)$ & - & - & - \\
\hline $4{ }^{\circ} \mathrm{C}$ & $(+)$ & + & $-*$ & + & + & - & + & $(+)$ & $(+)$ & + & + \\
\hline $37{ }^{\circ} \mathrm{C}$ & - & - & + & - & - & + & - & - & - & + & $(+)$ \\
\hline \multicolumn{12}{|l|}{ Assimilation of: } \\
\hline Adonitol & + & - & - & - & - & - & - & - & - & - & - \\
\hline Sorbitol & + & - & - & - & - & - & - & - & - & - & + \\
\hline Phenylacetate & + & - & - & - & - & - & - & - & - & ND & ND \\
\hline D-Galactose & + & + & - & - & - & - & - & - & $(+)$ & + & $(+)$ \\
\hline D-Mannose & - & + & - & - & $(+)$ & $(+)$ & - & - & $(+)$ & - & $(+)$ \\
\hline D-Ribose & - & $(+)$ & - & - & - & $(+)$ & - & - & $(+)$ & + & $\mathrm{ND}$ \\
\hline D-Glucose & - & - & - & - & $(+)$ & $(+)$ & - & - & $(+)$ & + & - \\
\hline D-Fructose & - & - & - & - & $(+)$ & - & - & - & $(+)$ & + & $(+)$ \\
\hline Cellobiose & - & - & - & - & - & $(+)$ & - & - & $(+)$ & + & + \\
\hline $\begin{array}{l}N \text {-Acetyl-D-glucos- } \\
\text { amine }\end{array}$ & + & - & - & - & - & $(+)$ & - & - & - & - & $(+)$ \\
\hline Sucrose & - & - & - & - & $(+)$ & - & - & - & - & + & + \\
\hline Adipate & + & - & - & - & - & $(+)$ & - & - & - & ND & ND \\
\hline Citrate & + & - & - & - & - & $(+)$ & - & - & - & - & - \\
\hline Arginine dihydrolase & - & + & - & $\mathrm{ND}$ & - & $\mathrm{ND}$ & - & - & - & - & ND \\
\hline Urease & - & + & - & ND & - & - & - & - & - & - & - \\
\hline \multicolumn{12}{|c|}{ API ZYM (enzyme activities) } \\
\hline Alkaline phosphatase & + & + & + & ND & + & + & + & + & + & + & + \\
\hline Leucine arylamidase & + & + & $(+)$ & ND & + & + & + & + & + & + & + \\
\hline Cystine arylamidase & - & + & - & $\mathrm{ND}$ & - & + & - & - & - & $(+)$ & $(+)$ \\
\hline Valine arylamidase & - & + & - & $\mathrm{ND}$ & + & + & - & $(+)$ & $(+)$ & - & + \\
\hline $\begin{array}{l}\text { Naphthol-AS-BI- } \\
\text { phosphohydrolase }\end{array}$ & - & + & $(+)$ & ND & + & ND & $(+)$ & $(+)$ & + & + & + \\
\hline Esterase (C4) & + & + & - & ND & + & ND & $(+)$ & $(+)$ & $(+)$ & + & + \\
\hline Esterase lipase (C8) & + & + & $(+)$ & ND & + & + & $(+)$ & $(+)$ & $(+)$ & + & + \\
\hline$\alpha$-Galactosidase & - & $(+)$ & - & + & - & - & - & - & - & - & - \\
\hline$\beta$-Galactosidase & - & + & - & $\mathrm{ND}$ & - & - & - & - & - & - & - \\
\hline$\alpha$-Glucosidase & - & + & - & + & - & ND & - & - & - & - & - \\
\hline$\beta$-Glucosidase & - & $(+)$ & - & + & - & - & - & - & $(+)$ & $(+)$ & + \\
\hline $\begin{array}{l}N \text {-Acetyl- } \beta \text {-glucos- } \\
\text { aminidase }\end{array}$ & - & $(+)$ & - & ND & - & + & - & - & - & + & + \\
\hline Acid phosphatase & + & + & - & ND & + & + & - & - & $(+)$ & + & + \\
\hline Growth on $\dagger$ & $\mathrm{R} 2 \mathrm{~A}$ & $\mathrm{R} 2 \mathrm{~A}$ & $\begin{array}{c}\text { PYES, } \\
\text { R2A, } \\
\text { C-D, TSA }\end{array}$ & $\begin{array}{c}\text { PYGV, } \\
\text { R2A }\end{array}$ & $\begin{array}{r}\text { PYES, } \\
\text { R2A, } \\
\text { TSA }\end{array}$ & $\begin{array}{l}\text { YP, } \\
\text { TSA }\end{array}$ & $\begin{array}{r}\text { PYES, R2A, } \\
\text { C-D, TSA }\end{array}$ & $\begin{array}{r}\text { PYES, R2A, } \\
\text { C-D, TSA }\end{array}$ & $\begin{array}{r}\text { PYES, } \\
\text { R2A }\end{array}$ & $\begin{array}{c}\text { TSA, Nu, } \\
\text { R2A }\end{array}$ & $\begin{array}{l}\text { TSA, } \\
\text { PYES }\end{array}$ \\
\hline No growth on $\dagger$ & TSA, MC & $\begin{array}{r}\text { TSA, } \\
\text { MC }\end{array}$ & $\mathrm{MC}$ & ND & $\begin{array}{r}\mathrm{C}-\mathrm{D} \\
\mathrm{MC}\end{array}$ & ND & MC & $\mathrm{MC}$ & $\begin{array}{l}\text { TSA } \\
\text { C-D, MC }\end{array}$ & ND & $\mathrm{ND}$ \\
\hline Source of isolation & Sediment & Soil & Soil & Soil & Air & Pork & Soil & Soil & Air & Freshwater & Desert \\
\hline $\begin{array}{l}\text { DNA G }+ \text { C content } \\
(\mathrm{mol} \%)\end{array}$ & 62.2 & 58.8 & $\sim 65$ & 56 & 63.1 & 62 & 61 & $57-58$ & ND & 65 & 54 \\
\hline
\end{tabular}

${ }^{*}$ No growth at $5{ }^{\circ} \mathrm{C}$ (Collins et al., 2000).

$\nmid \mathrm{C}-\mathrm{D}$, Czapek-Dox agar; MC, MacConkey agar; Nu, nutrient agar/broth; PYES, PYES agar (Buczolits et al., 2002); PYGV, peptone-yeast extractglucose-vitamins; TSA, trypticase soy agar; YP, yeast extract-peptone broth.

$\ddagger$ Poor growth on this medium. 


\section{Acknowledgements}

This work was supported by the 21C Frontier Microbial Genomics and Application Center Program, Ministry of Science \& Technology (Grant MG05-0101-4-0), South Korea.

\section{References}

Atlas, R. M. (1993). Handbook of Microbiological Media. Edited by L. C. Parks. Boca Raton, FL: CRC Press.

Baik, K. S., Seong, C. N., Moon, E. Y., Park, Y.-D., Yi, H. \& Chun, J. (2006). Hymenobacter rigui sp. nov., isolated from wetland freshwater. Int J Syst Evol Microbiol 56, 2189-2192.

Benson, D. A., Karsch-Mizrachi, I., Lipman, D. J., Ostell, J. \& Wheeler, D. L. (2005). GenBank. Nucleic Acids Res 33, D34-D38.

Buck, J. D. (1982). Nonstaining ( $\mathrm{KOH})$ method for determination of gram reactions of marine bacteria. Appl Environ Microbiol 44, 992-993.

Buczolits, S., Denner, E. B. M., Vybiral, D., Wieser, M., Kämpfer, P. \& Busse, H. J. (2002). Classification of three airborne bacteria and proposal of Hymenobacter aerophilus sp. nov. Int J Syst Evol Microbiol 52, 445-456.

Buczolits, S., Denner, E. B. M., Kämpfer, P. \& Busse, H. J. (2006). Proposal of Hymenobacter norwichensis sp. nov., classification of 'Taxeobacter ocellatus', 'Taxeobacter gelupurpurascens' and 'Taxeobacter chitinovorans' as Hymenobacter ocellatus sp. nov., Hymenobacter gelipurpurascens sp. nov. and Hymenobacter chitinivorans sp. nov., respectively, and emended description of the genus Hymenobacter Hirsch et al. 1999. Int J Syst Evol Microbiol 56, 2071-2078.

Cole, J. R., Chai, B., Farris, R. J., Wang, Q., Kulam, S. A., McGarrell, D. M., Garrity, G. M. \& Tiedje, J. M. (2005). The Ribosomal Database Project (RDP-II): sequences and tools for high-throughput rRNA analysis. Nucleic Acids Res 33, D294-D296.

Collins, M. D., Hutson, R. A., Grant, I. R. \& Patterson, M. F. (2000). Phylogenetic characterization of a novel radiation-resistant bacterium from irradiated pork: description of Hymenobacter actinosclerus sp. nov. Int J Syst Evol Microbiol 50, 731-734.

Fautz, E. \& Reichenbach, H. (1980). A simple test for flexirubin-type pigments. FEMS Microbiol Lett 8, 87-91.

Felsenstein, J. (1985). Confidence limits on phylogenies: an approach using the bootstrap. Evolution 39, 783-791.

Garrity, G. M. \& Holt, J. G. (2001). The road map to the Manual. In Bergey's Manual of Systematic Bacteriology, 2nd edn, pp. 119-166. Edited by D. R. Boone, R. W. Castenholz \& G. M. Garrity. New York: Springer.

Hall, T. A. (1999). BioEdit: a user-friendly biological sequence alignment editor and analysis program for Windows 95/98/NT. Nucleic Acids Symp Ser 41, 95-98.

Hiraishi, A., Ueda, Y., Ishihara, J. \& Mori, T. (1996). Comparative lipoquinone analysis of influent sewage and activated sludge by highperformance liquid chromatography and photodiode array detection. J Gen Appl Microbiol 42, 457-469.

Hirsch, P., Ludwig, W., Hethke, C., Sittig, M., Hoffmann, B. \& Gallikowski, C. A. (1998). Hymenobacter roseosalivarius gen. nov., sp. nov. from continental Antarctica soils and sandstone: bacteria of the Cytophaga/Flavobacterium/Bacteroides line of phylogenetic descent. Syst Appl Microbiol 21, 374-383.
Im, W.-T., Kang, M. S., Park, H. Y., Kim, M.-K. \& Lee, S.-T. (2003). Culturable bacterial strain's diversity of environmental samples. In Proceedings of the International Meeting of the Federation of Korean Microbiological Societies, abstract B4023, p. 165. Seoul: Federation of Korean Microbiological Societies.

Kim, M.-K., Im, W.-T. \& Lee, S.-T. (2008). Hymenobacter soli sp. nov., isolated from grass soil. Int J Syst Evol Microbiol 58, 211-213.

Kimura, M. (1983). The Neutral Theory of Molecular Evolution. Cambridge: Cambridge University Press.

Kouker, G. \& Jaeger, K.-E. (1987). Specific and sensitive plate assay for bacterial lipases. Appl Environ Microbiol 53, 211-213.

Kumar, S., Tamura, K. \& Nei, M. (2004). MEGA3: integrated software for Molecular Evolutionary Genetics Analysis and sequence alignment. Brief Bioinform 5, 150-163.

Mesbah, M. \& Whitman, W. B. (1989). Measurement of deoxyguanosine/thymidine ratios in complex mixtures by high-performance liquid chromatography for determination of the mole percentage guanine + cytosine of DNA. J Chromatogr 479, 297-306.

Moore, D. D. \& Dowhan, D. (1995). Preparation and analysis of DNA. In Current Protocols in Molecular Biology, pp. 2-11. Edited by F. W. Ausubel, R. Brent, R. E. Kingston, D. D. Moore, J. G. Seidman, J. A. Smith \& K. Struhl. New York: Wiley.

Saitou, N. \& Nei, M. (1987). The neighbor-joining method: a new method for reconstructing phylogenetic trees. Mol Biol Evol 4, 406425.

Sasser, M. (1990). Identification of bacteria by gas chromatography of cellular fatty acids, MIDI Technical Note 101. Newark, DE: MIDI Inc.

Ten, L. N., Im, W.-T., Kim, M.-K., Kang, M.-S. \& Lee, S.-T. (2004). Development of a plate technique for screening of polysaccharidedegrading microorganisms by using a mixture of insoluble chromogenic substrates. J Microbiol Methods 56, 375-382.

Ten, L. N., Jung, H.-M., Yoo, S.-A., Im, W.-T. \& Lee, S.-T. (2008). Lysobacter daecheongensis sp. nov., isolated from sediment of stream near the Daechung dam in South Korea. J Microbiol 46, 519-524.

Thompson, J. D., Gibson, T. J., Plewniak, F., Jeanmougin, F. \& Higgins, D. G. (1997). The CLUSTAL_X windows interface: flexible strategies for multiple sequence alignment aided by quality analysis tools. Nucleic Acids Res 25, 4876-4882.

Tschech, A. \& Pfennig, N. (1984). Growth yield increase linked to caffeate reduction in Acetobacterium woodii. Arch Microbiol 137, 163167.

Widdel, F. \& Bak, F. (1992). Gram-negative mesophilic sulfate reducing bacteria. In The Prokaryotes, 2nd edn, pp. 3352-3378. Edited by A. Balows, H. G. Trüper, M. Dworkin, W. Harder \& K. H. Schleifer. New York: Springer-Verlag.

Widdel, F., Kohring, G.-W. \& Mayer, F. (1983). Studies on dissimilatory sulfate-reducing bacteria that decompose fatty acids. III. Characterization of the filamentous gliding Desulfonema limicola gen. nov. sp. nov., and Desulfonema magnum sp. nov. Arch Microbiol 134, 286-294.

Zhang, Q., Liu, C., Tang, Y., Zhou, G., Shen, P., Fang, C. \& Yokota, A. (2007). Hymenobacter xinjiangensis sp. nov., a radiation-resistant bacterium isolated from the desert of Xinjiang, China. Int J Syst Evol Microbiol 57, 1752-1756. 